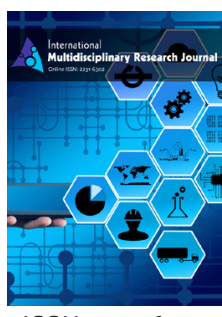

ISSN: 2231-6302
Received: October 15, 2020 Accepted: November 25, 2020 Published: December 04, 2020

*Corresponding Author: Janet Orero Obiero, E-mail: obierojanet@gmail. com

\section{An investigation into the study habits of distance learners: Implications for personal guidance and counselling at University of Nairobi, Kenya}

\author{
Janet Orero Obiero ${ }^{1,2^{*}}$, Anne Assey ${ }^{1}$, Charles Kimamo' \\ 'University of Nairobi. Kenya, ${ }^{2} T e c h n i c a l$ University of Kenya
}

\begin{abstract}
Quality and sustainability have been unresolved issues since repercussion of commercialization of distance education. Personal guidance, counselling and study habits, which are critical in maintaining quality of distance education, have been underrated in most distance education. The study investigated influence of personal guidance and counselling on study habits of distance learners in Bachelor of Education of University of Nairobi. 319 respondents participated in the study by filling in questionnaires. The results of Pearson Correlation Coefficient showed a positive correlation $\mathrm{R}=0637$ between personal guidance and counselling and study habits. Hypothesis was tested at $\alpha=.05$ level of significance and the results H01: Personal guidance and counselling does not significantly influence study habits of distance learners was rejected since $\mathrm{P}=0.000<0.05$. Therefore, the study concluded that there is significant influence of personal guidance and counselling support services on study habits of distance learners in Bachelor of Education studies of the University of Nairobi. The study recommend a paradigm shift through face to face and digital technology in provision of personal guidance and counselling for study habits to maintain quality of distance education.
\end{abstract}

KEYWORDS: Personal guidance, counselling, study habits, distance learners, support services

\section{INTRODUCTION}

Distance education has become more indispensable part of global education following the emergence of the COVID 19 pandemic. It is opening up access to higher education for learners who cannot attend on-campus learning (UNESCO, Global Education Monitoring (GEM) Report, 2020). The transition to University independent learning is turning out to be too stressful for many distance education learners, since COVID19 pandemic has pushed the world into the deepest global recession. This mode of study exposes learners to psychosocial vulnerabilities. There is concern over a rise in number of cases of anxiety, sexual dysfunctions, emotional distress, behavioural challenges and other forms of psychological disturbances amongst distance learners. Consequently, there are reports of distance learners exhibiting deviational study habits that lower progression and completion rate [1]. Subsequently personal guidance, counselling and study habits become mandatory for quality and sustainability of distance education.

Developing good study habits of distance learners is a complex phenomenon that requires sound personal guidance and counselling support services [2]. Deviational study habits result in lack of ability to set personal study goals, plan study routine and complete assignment in time [3]. Personal guidance and counselling empower learners to cope with the problems of the mind and issues of life adjustment to self-regulated study [4]. They are also critical in helping individual distance learners to cope with anxiety over examinations, lingering anger, depressive feelings and persistence in study [5]. Furthermore, personal guidance and counselling enable distance learners to have patience and control of their study time with less anxiety [6]. When learners lack personal guidance and counselling, learning speed is slowed leading to deviational study habits [7].

Distance education has developed through phases into mega open Universities in America, Europe, India, China, and South Africa with stronger learners' support services [8]. In Open Universities where personal guidance and counselling are offered to distance learners, increase in enrolment, and completion rates are noted. Personal guidance and counselling is given through digital technology to thousand distance learners [9]. The developing countries' Universities that offer learning and teaching through distance mode are struggling to

Copyright: $\odot$ The authors. This article is open access and licensed under the terms of the Creative Commons Attribution License (http://creativecommons.org/licenses/by/4.0/) which permits unrestricted, use, distribution and reproduction in any medium, or format for any purpose, even commercially provided the work is properly cited. Attribution - You must give appropriate credit, provide a link to the license, and indicate if changes were made. 
update learners' support systems like personal guidance and counselling into technology-enabled environment. This is not the case in most distance education Universities especially in Africa [10] internet connectivity and resource is a challenge. Personal guidance and counselling are not considered as an integral part of the core business in African Universities that offer distance education [11]. In Kenya, the utilization of personal guidance and counselling support services in public universities is mirage, though there has been considerable effort to make personal guidance and counselling support services available to all learners [12]. The University of Nairobi is one of such universities struggling to embrace technology in learners' support. All these have contributed to difficulties in providing personal guidance and counselling to large number of distance learners leading deviational study habits.

The Bachelor of Education programmes by distance learning of University of Nairobi has been successful in upgrading academic qualifications to thousands prospective teachers. This success is not without study barriers common to learners in distance education globally. Some of the learners in this Programme may have been spoon-fed, and taught for examination. Besides, limited studies have been done to address personal guidance and counselling and study habits of distance learners.

\section{LITERATURE REVIEW}

\section{Personal Guidance and Counselling Support Services and Study Habits}

Personal guidance and counselling support services in distance education in literature reviewed promote increased attendance during tutorial sessions and progression to desired educational destination. Such services reduce distance learners' stress that interfere with concentration in study. The following are some gaps that the study attempted to fulfil.

Tucker [13] carried a study on learners' perception on quality and effectiveness of personal guidance and counselling services on study habits at Zimbabwe Open University. The study used survey design, and simple sampling method to select 250 participants. The study also used questionnaires to collect quantitative data. The data was analysed using both descriptive and inferential statistics. The study results indicated that effective personal guidance and counselling enable distance learners to deal with psychological problems they may experience and make rational decisions on how to solve or cope with the academic, social and personal challenges. The study failed to explain how sample size of 250 was selected. The study also employed descriptive survey research but limited to quantitative data leaving out qualitative data. While the current study employed both quantitative and qualitative approaches to determine the influence of personal guidance and counselling on study habits of learners in Bachelor of Education programme by distance learning programme.

Kangai et al. [14] carried out a study on students' perceptions on the quality and effectiveness of guidance and counselling services at the Zimbabwe Open University. Data was collected from simple a random sample of 200 learners registered at the ZOU for the academic year 2010, through a survey research design that employed questionnaires. The study findings indicate that majority of distance learners $80 \%$ of who live and work in the rural areas, needed quality and effective personal guidance and counselling and general academic support in the following area: Distribution of learning materials (modules), management of coursework (assignments), tutorials, processing of examinations and communication. The study relied on quantitative data only ignoring qualitative data yet the research employed descriptive research design. The current study provided target population and how sample size was arrived at which was lacking in the above study. The current study adopted different methodology to investigate the influence of personal guidance and counselling on study habits of distance learners.

Nyaga et al. [15] study on effectiveness of guidance and counselling services on development of learners' academic competence: A comparative study of public and private universities in Kenya. The study employed ex-post facto casual comparative design and the t- test statistical technique for analysis. The study collected both quantitative and qualitative data by use of a questionnaire and interview. The study used stratified random sampling technique to select 408 participants. The study indicated that through effective personal guidance and counselling services, learners in private universities had better growth in the academic competence than those enrolled in public universities. This study did not provide total target population and only used quantitative data. Despite the appropriateness of research methodology of the study, the research design is different from the one used in this study. The study focussed on effectiveness of guidance on academic competence while current study focus was on influence of guidance and counselling on study habits of distance learners.

\section{METHODOLOGY}

This study adopted a descriptive survey research design to plan well and build the content of the research. The sample size for respondents in this study was 327 determine in accordance to Krejcie, (2006) table of determining sample size drawn from a target population of 2199 learners in Bachelor of Education by distance programmes of the University of Nairobi. The study used structured questionnaires to collect data. The pilot test conducted to correct any faults, restrictions, or other in questionnaire. This study adopted content validity (also known as logical validity). Split half used to test reliability. The corresponding optimal values of Cronbach's alpha used as a measure of internal consistency. The overall instrument had a reliability coefficient of 0.755 . Multiple linear regression model employed to establish the simultaneous influence of personal guidance and counselling support services on the study habits of distance learners by distance learning in The University of Nairobi. The relationship between personal guidance and counselling support services and study habits of learners in Bachelor of Education by distance learning of University of Nairobi developed into linear regression model as follows. 
$\mathrm{Y}_{\mathrm{i}}=\beta_{0}+\beta_{\mathrm{i}} \mathrm{X}_{\mathrm{i}}+\beta_{\mathrm{mi}} \mathrm{X}_{\mathrm{m}}+\varepsilon$

Where:

$\mathrm{Y}_{\mathrm{i}-\text { The dependent variable }}$

$\beta_{0}^{-}$- Population's regression constant

$\beta_{\mathrm{i}}(\mathrm{i}=1,2 \ldots \mathrm{n})$ are the population's regression coefficient

$n$ coefficients for each independent variable

$\mathrm{X}_{\mathrm{i}-}$ The potential predictors

$\beta_{\text {mi }}$ regression coefficient of the moderating variable

$\mathrm{X}_{\mathrm{mi-}}^{\mathrm{mi}-}$ Moderating variable (learners characteristics)

$\varepsilon$-is the Model error variable.

Study habits of distance learners $=\beta 0+\beta$ i personal *guidance and counselling support services $+\beta \mathrm{mi}$ * learners characteristics + Model error. This relationship was assumed to hold for all observations $(i=1,2 \ldots n)$. The inclusion of a random error, $\varepsilon i$, was necessary because other unspecified variables also affected study habits of distance learners. The regression model based on the following assumptions, normality, linearity, homogeneity of variance and multi collinearity. Based on the hypothesis generated the following model was adopted;

Hypothesis; $\mathrm{H}_{1}$ : There is an insignificant relationship between personal guidance and counselling and study habits of learners in Bachelor of Education Programme by distance learning in the University.

Study habits of distance learners $=f$ (Personal guidance and counselling support services, random error)

$Y_{j}=\beta_{0}+\beta_{1} X_{1}+\varepsilon_{i}$

Where $\beta_{0}$ - Population's regression constant, $X_{\text {one - Personal }}$ guidance and counselling, $\beta_{\mathrm{i}}$ the regression coefficient of personal guidance and counselling and $\varepsilon$-is the Model error variable. Data were organized in thematic area. Systematic analysis and interpretation of interim report integrated with quantitative output to form the paper.

\section{RESULTS AND DISCUSSION}

The objective that the study sought to achieve was to establish the extent to which personal guidance and counselling influence the study habits of distance learners in the Bachelor of Education programmes of the University of Nairobi. The participants were requested to give their opinions on their level of agreements or disagreements with the statements on a Likert scale of 1-5 where Strongly agree $(\mathrm{SA})=\operatorname{Agree}(\mathrm{A})=4$ Undecided $(\mathrm{U})=\operatorname{Disagree}(\mathrm{D})=2$ and Strongly disagree $(\mathrm{SD})=1$. The results presented in Table 1 .

Ten statements developed to measure the extent to which personal guidance and counselling influence study habits of learners in Bachelor of Education by distance learning. Statement (PGCl) 'Personal guidance and counselling have helped me to manage my anxieties' had a mean of 2.97 and a standard deviation of 1.36 . These results indicate that out of 319 participants $116(36.4 \%)$ agreed. 68 (21.3\%) strongly disagreed,
$60(18.8 \%)$ disagreed. 39 (12.2\%) were undecided and $36(11.3 \%)$ strongly agreed that personal guidance and counselling have helped me to manage my anxieties. These results show that the line item score of 2.97 and standard deviation of 1.36 were below the composite mean score of 3.13 and standard deviation of 1.346; This result implies that personal guidance and counselling offered at the University of Nairobi is not effective enough to help distance learners manage their anxieties. The result finding contradicts findings by Moor and Kersley [16] who found out that personal guidance and counselling reduces distance learners' anxiety and personal distress.

Statement (PGC2) 'Personal guidance and counselling have helped me to increase my abilities to make decisions' had a mean of 3.13 and a standard deviation of 1.353 . These results indicate that out of 319 participants $129(40.4 \%)$ agreed, 59(18.5\%) strongly disagreed, 54(16.9\%) disagreed, 42(12.2\%) strongly agreed and $35(11.0 \%)$ were undecided that personal guidance and counselling have helped them to manage their anxieties. This results shows that the line item mean score of 3.13 and standard deviation of 1.353 were nearly similar to the composite mean score of 3.13 and standard deviation of 1.346; This result suggests that personal guidance and counselling have some positive influence in increasing the ability of distance learners to make decision. This finding is in line with Tsikati [5] who found out that personal guidance and counselling has some positive influence in increasing the ability of distance learners to make decisions.

Statement (PGC3) 'Personal guidance and counselling have enabled me to have self-regulation study' had a mean of 3.12 and a standard deviation of 1.323 . These results indicate that out of 319 participants; $123(38.6 \%)$ agreed, 57(17.9\%) strongly disagreed, $50(15.7 \%)$ disagreed, $49(15.4 \%)$ were undecided on whether personal guidance and counselling have enabled them to have self-regulation and $40(12.5 \%)$ who strongly agreed that personal guidance and counselling have enabled them to have self-regulation. These results show that the line item mean score of 3.12 and standard deviation of 1.323 were slightly below the composite mean score of 3.13 and standard deviation of 1.346; This result implies that personal guidance and counselling slightly influence self-regulation of learners' study habits. The implication of this results to this study is that personal guidance and counselling offered to the participants are not adequate enough to enable them develop effective study habits for independent learning. This result does not support finding by Simpson and Gibbs [17] who found that personal guidance and counselling support services are more often a case of a quietly conscious helping process in issues of self-regulation.

Statement (PGC 4) 'Personal guidance and counselling helped me to resolve personal conflicts' had a mean of 3.14 and a standard deviation of 1.383 . These results indicate that out of 319 participants, $116(36.4 \%)$ agreed, 62(19.4\%) disagreed, $57(17.9 \%)$ strongly disagreed, $52(16.3 \%)$ strongly agreed and $32(10.0 \%)$ who were undecided on whether personal guidance and counselling helped them to resolve personal conflicts. These results shows that the line item mean score of 3.14 and standard deviation of 1.383 were above the composite mean score of 
Table 1: Personal guidance and counselling and study habits of distance learners

\begin{tabular}{|c|c|c|c|c|c|c|c|}
\hline Statements & SA & $A$ & UD & D & SD & Mean & Std. dev \\
\hline PGCl & $36(11.3 \%)$ & $116(36.4 \%)$ & $39(12.2 \%)$ & $60(18.8 \%)$ & $68(21.3 \%)$ & 2.97 & 1.36 \\
\hline PGC2 & $42(13.2 \%)$ & $129(40.4 \%)$ & $35(11.0 \%)$ & $54(16.9 \%)$ & $59(18.5 \%)$ & 3.13 & 1.353 \\
\hline PGC3 & $40(12.5 \%)$ & $123(38.6 \%)$ & $49(15.4 \%)$ & $50(15.7 \%)$ & $57(17.9 \%)$ & 3.12 & 1.323 \\
\hline PGC4 & $52(16.3 \%)$ & $116(36.4 \%)$ & $32(10 \%)$ & $62(19.4 \%)$ & $57(17.9 \%)$ & 3.14 & 1.383 \\
\hline PGC5 & $43(13.5 \%)$ & $114(35.7 \%)$ & $50(15.7 \%)$ & $59(18.5 \%)$ & $53(16.6 \%)$ & 1.38 & 0.740 \\
\hline PGC6 & $46(14.4 \%)$ & $128(40.1 \%)$ & $41(12.9 \%)$ & $53(16.6 \%)$ & $51(16.0 \%)$ & 3.20 & 1.322 \\
\hline PGC7 & $35(11.0 \%)$ & $145(45.5 \%)$ & $29(9.0 \%)$ & $58(18.2 \%)$ & $52(16.3 \%)$ & 3.17 & 1.306 \\
\hline PGC8 & $48(15.0 \%)$ & $125(39.2 \%)$ & $34(10.7 \%)$ & $61(19.1 \%)$ & $51(16.0 \%)$ & 3.18 & 1.341 \\
\hline PGC9 & $45(14.1 \%)$ & $105(32.9 \%)$ & $47(14.7 \%)$ & $61(19.2 \%)$ & $61(19.1 \%)$ & 3.04 & 1.362 \\
\hline PGClO & $48(15.0 \%)$ & $115(36.2 \%)$ & $39(12.2 \%)$ & $62(19.4 \%)$ & $55(17.2 \%)$ & 3.12 & 1.355 \\
\hline Composite mean and standard deviation & & & & & & 3.13 & 1.346 \\
\hline
\end{tabular}

N.B PGC1-10 (Personal guidance and counselling Statements

3.13 and standard deviation of 1.346. The results suggest that personal guidance and counselling have positive influence on resolution of personal conflict amongst learners in Bachelor of Education programme by distance learning of the university of Nairobi which is an indicator of sound study habits. The result contradicts Wango [18] who found that distance learners do not get adequate personal guidance and counselling at the University of Nairobi because the learners' counsellors are few.

Statement (PGC5) 'Personal guidance and counselling have assisted me to acquire personal patience in reading' had a mean of 3.11 and a standard deviation of 1.319. These results indicate that out of 319 participants, $114(35.7 \%$ agreed, 59(18.5\%) disagreed, 53(16.6\%) strongly disagreed and 50(15.7\%) were undecided on whether personal guidance and counselling have assisted them to acquire personal patience in reading and $43(13.5 \%)$ who strongly agreed that personal guidance and counselling have assisted them to acquire personal patience in reading. These results shows that the line item mean score of 1.38 and standard deviation of 0.74 were below the composite mean score of 3.13 and standard deviation of 1.346. The implication of this result to the study is personal guidance and counselling does not help learners in Bachelor of Education by distance learning in acquiring patience while reading. The study results support Wachira [12] who suggested that there is inadequate seeking for personal guidance and counselling support services by all learners in Universities in Kenya because of time and lack of professional counsellors.

Statement (PGC6) 'Personal guidance and counselling have helped me to develop skills of attaining goals' had a mean of 3.20 and a standard deviation of 1.322 . These results indicate that out of 319 participants, $128(40.1 \%)$ agreed, 53(16.6\%) disagreed, $51(16.0 \%)$ strongly disagreed, 46(14.4\%) strongly agreed and $41(12.9 \%)$ were undecided on whether personal guidance and counselling have helped them to develop skills of attaining goals. This results shows that line item mean score of 3.20 and standard deviation of 1.322 were above the composite mean score of 3.13 and standard deviation of 1.346 . The implication of the result to the study is that personal guidance and counselling help distance learners in developing skills for attaining goals. This result confirms Hooley and Rice [3] who revealed that personal guidance and counselling help distance learners to develop skills of attaining personal goals, an attribute of positive study habits.
Statement (PGC7) 'Personal guidance and counselling have assisted me to do self-assessment' had a mean of 3.17 and a standard deviation of 1.305 . These results indicate that out of 319 participants, $145(45.5 \%)$ agreed, 58(18.2\%) disagreed, $52(16.3 \%)$ strongly disagree, $35(11.0 \%)$ strongly and $29(9.10 \%)$ of the distance learners were undecided on whether personal guidance and counselling have assisted them to do selfassessment. These results show that the line item mean score of 3.17 and standard deviation of 1.306 were above the composite mean score of 3.13 and standard deviation of 1.346 . The implication of the result to the study is that personal guidance and counselling moderately influence distance learners to do self-assessment, which slightly influence their study habits. The study result contradicts [10] who found out that the influence of personal guidance and counselling on issues like study habits have remained a mirage in public universities in Kenya.

Statement (PGC8) 'Personal guidance and counselling have helped me to attain self-motivation to study' had a mean of 3.18 and a standard deviation of 1.341 . These results indicate that out of 319 participants, 125(39.2\%) agreed, 61 (19.1\%) disagreed, $51(16.0 \%)$ strongly disagreed, 48(15.0\%) strongly agreed and $34(10.7 \%)$ were undecided on whether that personal guidance and counselling have helped them to attain self-motivation. These results show that the line item mean score of 3.18 and standard deviation of 1.341 were above the composite mean score of 3.13 and standard deviation of 1.346; This result implies that personal guidance and counselling positively influence learners attain self-motivation to study which enhances their study habits. This study confirms findings by Krishna [19] who found that personal guidance and counselling positively influence learners attain self-motivation to study, which enhances their study habits.

Statement (PGC9) 'Personal guidance and counselling have helped me to cope with personal family issues' had a mean of 3.04 and a standard deviation of 1.362 . These results indicate that out of 319 participants, 105(32.9\%) agreed, 61 (19.1\%) both disagreed as well as strongly disagreed, 47 (14.7\%) were undecided on whether personal guidance and who strongly agreed that personal guidance and counselling have helped them to cope with personal family issues. This results show that the line item mean score of 3.04 and standard deviation 
of 1.362 were below the composite mean score of 3.13 and standard deviation of 1.346. The implication of this result to the study is that personal guidance and counselling do not help distance learners cope with family issues, which contribute to infective study habits. The result concur with Wachira [12] who found out that distance learners are preoccupied with family issues which deny them time to seek personal guidance and counselling to improve their study habit.

Statement (PGC10) 'Personal guidance and counselling have helped me to increase my ability to steer and control my emotions' had a mean of 3.12 and a standard deviation of 1.305 . This results indicate that out of 319 participants, $115(36.1 \%)$ agreed 62(19.4\%).disagreed, 55 (17.2\%) strongly disagreed. 48(15.0\%) strongly agreed and 39 (12.2\%) who were undecided on whether personal guidance and counselling have helped them to increase their ability to steer and control their emotions. These results show that the line item mean score of 3.12 and standard deviation of 1.355 were slightly below the composite mean score of 3.13 and standard deviation of 1.346 . The implication of this result to the study is that personal guidance and counselling do not help distance learners to steer, control emotions, and end up with inadequate study habits. The study result concurs with Wango [18] who found out that personal guidance and counselling is not effective in public Universities due to large number of students.

The result suggest that the Statement moderately influence study habits of distance learners positively. Out of the ten statements of personal guidance and counselling; personal guidance and counselling have helped me to develop skills of attaining goals had the highest mean (mean=3.20). The result indicates that majority of learners tended to agree unanimously that personal guidance and counselling have helped them to develop skills of attaining goals. Variability was lower $(\sigma=1.306)$ for Statement 7 'personal guidance and counselling have assisted me to do self-assessment.' The results suggest that Distance learners in Bachelor of Education programme by distance learning were homogeneous among themselves that personal guidance and counselling have assisted them to do self-assessment.

The composite mean and composite deviation for the personal guidance and counselling were 3.13 and 1.346 respectively. The implication of the result to the study that based from responses on Likert scale the distance learners were undecided on whether personal guidance and counselling influence study habits of distance learners. The results are consistent with findings by Kraatz (2015) who found out that personal guidance and counselling moderately influences study habits of distance learners. These findings were further supported by responses from participants through open-ended questionnaires said that the University provide personal guidance and counselling services to them through online. The moderate influence of such services is seen in managing their anxieties, increasing their abilities to make decisions, resolving personal conflicts, acquiring personal patience in reading and attainment of selfmotivation to study.

\section{Correlation Analysis on Personal Guidance and Counselling and Study Habits of Distance Learners}

Pearson correlation coefficient used to test the relationship between personal guidance and counselling and study habits of Bachelor of Education by distance learning at $95 \%$ level of confidence. To test the extent of the relationship between personal guidance, counselling, study habits of Distance learners in Bachelor of Education programme by distance learning, several characteristics of personal guidance and counselling, and study habits were analysed based on the following hypothesis. ${ }_{\mathrm{H} 0}$ : There is no significant relationship between personal guidance and counselling on the study habits of Bachelor of Education by distance learning of the University of Nairobi.

The corresponding mathematical model for the hypothesis was identified as follows: Study habits of Bachelor of Education by distance learning $=\mathrm{f}$ (Personal guidance and counselling). To measure the influence of personal guidance and counselling on the study habits of distance learners using $95 \%$ level of confidence, the null hypothesis, $\mathrm{H}_{0}$ : There is no significant relationship between personal guidance and counselling on the study habits of learners in Bachelor of Education programme by distance learning was tested. All the P-values under significant 2 -tailed in Table 2 were found to be significant (P-values $<0.05$ ). Personal guidance and counselling have helped me to manage my anxieties (Statement $1 ; \mathrm{r}=0.439$, P-value $=0.000<0.05$ ). Personal guidance and counselling have helped me to increase my abilities to make decisions (Statement 2; $\mathrm{r}=0.467$, $\mathrm{P}$-value $=0.000<0.05)$. ${ }^{.}$Personal guidance and counselling have enabled me to have self-regulation' (Statement 3; $r=0.526$, P-value $=0.000<0.05)$. Personal guidance and counselling helped me to resolve personal conflicts (Statement 4; $r=0.566$, $\mathrm{P}$-value $=0.000<0.05)$. Personal guidance and counselling have assisted me to acquire personal patience in reading (Statement $5 ; \mathrm{r}=0.499$, P-value $=0.000<0.05)$, Personal guidance and counselling have helped me to develop skills of attaining goals (Statement 6; $r=0.511$, P-value $=0.000<0.05$ ), Personal guidance and counselling have assisted me to do self-assessment (Statement $7 ; \mathrm{r}=0.560$, P-value $=0.000<0.05)$, Personal guidance and counselling have helped me to attain self-motivation to study (Statement 8; r $=0.508$, P-value $=0.000<0.05$ ), Personal guidance and counselling have helped me to cope with personal family issues (Statement 9; $\mathrm{r}=0.473$, P-value $=0.000<0.05$ ) and personal guidance and counselling have helped me to increase my ability to steer and control my emotions (Statement 10; $\mathrm{r}=0.541, \mathrm{P}$-value $=0.000<0.05)$.

Similarly the overall correlation coefficient for personal guidance and counselling and study habits of distance learners was found to be 0.543 with a p-value of $0.000<\alpha=0.05$. The implication of this result to the study is that there is a significant relationship between personal guidance and counselling and study habits of distance learners leading to rejection of the null hypothesis $\left(\mathrm{H}_{01}\right.$ : There is no significant relationship between personal guidance and counselling on the study habits of learners in Bachelor of Education programme by distance learning). This finding is in agreement with Bimrose, Kettunen and Goddard [20] 
who found that personal guidance and counselling positively influence study habits of distance learners. The correlations results obtained shown in Table 2 .

\section{Regression Analysis of Personal Guidance and Counselling Influence on Study Habits of Distance Learners}

The rational of using the simple regression model was to establish how personal guidance and counselling as a predictor significantly or insignificantly predicted study habits of distance learners in Bachelor of Education programmes by distance learning of the University of Nairobi. The model summary table 3 suggest that there is a positive correlation $(R=0.543)$ between personal guidance and counselling and the study habits of distance learners in Bachelor of Education programmes by distance learning of the University of Nairobi and those predicted by the regression model. In addition, $29.5 \%$ of the variance in the study habits of distance learners in Bachelor of Education programmes by distance learning of the University of Nairobi was explained by Personal guidance and counselling. The results are consistent with the findings of a study of Moor and Kersley [16] who found significant relationship between personal guidance and counselling and study habits of distance learners. The regression model summary presented in Table 3.

The study sought to establish if the regression model is best fit for predicting study habits of distance learners in Bachelor of Education programme by distance learning in University of Nairobi. The ANOVA results indicated that (F-statistics $(1,317)$ $=132.611$ is significant at $P$ value $0.000<0.05$. The implication of the regression model results that it is significantly better prediction of study habits of distance learners in Bachelor of Education programme by distance learning in University of Nairobi. The regression ANOVA output statistics results shown in Table 4.

The simple linear regression coefficients results indicated that there was significant influence of personal guidance and counselling and study habits of distance learners in Bachelor of Education programme by distance learning in University of Nairobi given P-Value $0.00<0.05$. The regression model for personal guidance and counselling was $y=1.797+0.461 \mathrm{X}_{1}$. The result imply that for each unit of personal guidance and counselling support services, study habits of distance learners marginally changed by 0.461 unit. The results are consistent with the findings of studies by Hartung and Vess [2] who found out a significance influence of personal guidance and counselling on study habits of distance learners. The regression coefficients results are in Table 5.

\section{Study Habits of Distance Learners}

Study habits of distance learners in Bachelor of education programme by distance learning of the University of Nairobi in this study was the dependent variable. Both theoretical and empirical review in this study showed that appropriate personal goals, hours of reading before examination, handing of assignment in time, improved study habits, sound study time and studying through networking are key indicators of Study habits of distance learners. To measure study habits of distance learner's eleven statements developed in the self-administered questionnaires. The views of the 319 research participants on Study habits of distance learners presented descriptively in the subsequent section.

The participants were requested to respond to the Items in the Likert scale of $1-5$ where strongly agree $(\mathrm{SA})=5$. Agree $(\mathrm{A})=4$. Undecided $(\mathrm{U})=3$. Disagree $(\mathrm{D})=2$. Strongly disagree. $(\mathrm{SD})=1$. The results presented in Table 6 .

Table 2: Correlations of Personal Guidance and Counselling and Study Habits of Distance Learners $(n=319)$

\begin{tabular}{|c|c|c|}
\hline Personal guidance and counselling statements & & Study habits of distance learners \\
\hline Personal guidance and counselling increased my abilities to make decisions & $\begin{array}{l}\text { Pearson correlation } \\
\text { sig. ( } 2 \text {-tailed) }\end{array}$ & $\begin{array}{l}0.439^{*} \\
0.000\end{array}$ \\
\hline Personal guidance and counselling have enabled me to have self-regulation & $\begin{array}{l}\text { Pearson correlation } \\
\text { sig. ( } 2 \text {-tailed) }\end{array}$ & $\begin{array}{l}0.467^{*} \\
0.000\end{array}$ \\
\hline $\begin{array}{l}\text { Personal guidance and counselling have helped me to resolve personal } \\
\text { conflicts }\end{array}$ & $\begin{array}{l}\text { Pearson correlation } \\
\text { sig. ( } 2 \text {-tailed) }\end{array}$ & $\begin{array}{l}0.526^{*} \\
0.000\end{array}$ \\
\hline $\begin{array}{l}\text { Personal guidance and counselling have assisted me to acquire personal } \\
\text { patience }\end{array}$ & $\begin{array}{l}\text { Pearson correlation } \\
\text { sig. ( } 2 \text {-tailed) }\end{array}$ & $\begin{array}{l}0.566^{*} \\
0.000\end{array}$ \\
\hline $\begin{array}{l}\text { Personal guidance and counselling have helped me to develop skills of } \\
\text { attaining goals }\end{array}$ & $\begin{array}{l}\text { Pearson correlation } \\
\text { sig. ( } 2 \text {-tailed) }\end{array}$ & $\begin{array}{l}0.499^{*} \\
0.000\end{array}$ \\
\hline Personal guidance and counselling have assisted me to do self-assessment & $\begin{array}{l}\text { Pearson correlation } \\
\text { sig. ( } 2 \text {-tailed) }\end{array}$ & $\begin{array}{l}0.511^{*} \\
0.000\end{array}$ \\
\hline $\begin{array}{l}\text { Personal guidance and counselling have helped me to attain self-motivation } \\
\text { to study }\end{array}$ & $\begin{array}{l}\text { Pearson correlation } \\
\text { sig. (2-tailed) }\end{array}$ & $\begin{array}{l}0.560^{*} \\
0.000\end{array}$ \\
\hline $\begin{array}{l}\text { Personal guidance and counselling have helped me to cope with personal } \\
\text { family issues }\end{array}$ & $\begin{array}{l}\text { Pearson correlation } \\
\text { sig. (2-tailed) }\end{array}$ & $\begin{array}{l}0.508^{*} \\
0.000\end{array}$ \\
\hline $\begin{array}{l}\text { Personal guidance and counselling study have increase my ability to steer } \\
\text { and control my emotions }\end{array}$ & $\begin{array}{l}\text { Pearson correlation } \\
\text { sig. ( } 2 \text {-tailed) }\end{array}$ & $\begin{array}{r}0.473 * \\
0.000\end{array}$ \\
\hline Personal guidance and counselling have helped me to manage my anxieties & $\begin{array}{l}\text { Pearson correlation } \\
\text { sig. (2-tailed) }\end{array}$ & $\begin{array}{l}0.541^{*} \\
0.000\end{array}$ \\
\hline Personal guidance and counselling(overall correlation) & $\begin{array}{l}\text { Pearson correlation } \\
\text { Sig.(2-tailed) }\end{array}$ & $\begin{array}{c}0.543^{*} \\
0.000\end{array}$ \\
\hline
\end{tabular}

*Correlation is Significant at 0.05 level (2-tailed) 
Statement (SHDLl) 'I have set appropriate personal goals for my study after receiving personal guidance and counselling support services' had a mean of 3.32 and a standard deviation of 1.23. This results indicate that out 319 participants, $37(11.6 \%)$ strongly agreed, $161(50.5 \%)$ agreed, $24(7.5 \%)$ were undecided, $61(19.1 \%)$ disagreed and 36(11.3\%) strongly disagreed that they set appropriate personal goals for their study after receiving personal guidance and counselling support services. The results shows that the line statement mean score of 3.32 and standard deviation of 1.23 were above the composite mean score of 3.23 and standard deviation of 1.07. This result implies that setting appropriate study goals by distance learners positively affect their study habits. The study results support finding by Hassan [21] who found out that academic performance of distance learners improve when they set study goals.

Table 3: Regression model summary table of personal guidance and counselling influence on the study habits of distance learners

\begin{tabular}{lcccc}
\hline \multicolumn{5}{c}{ Model Summary } \\
\hline Model & R & R Square & Adjusted R Square & $\begin{array}{c}\text { Std. Error of the } \\
\text { Estimate }\end{array}$ \\
\hline 1 & $0.543^{\mathrm{a}}$ & 0.295 & 0.293 & 0.89753 \\
\hline
\end{tabular}

a. Predictors: (Constant), Guidance and counselling support services

Table 4: An ANOVA of the regression of personal guidance and counselling and study habits of distance learners

\begin{tabular}{llccccc}
\hline Model & Sum of Squares & Df & Mean Square & $F$ & Sig. \\
\hline 1 & Regression & 106.826 & 1 & 106.826 & 132.611 & $0.000^{b}$ \\
& Residual & 255.363 & 317 & 0.805 & & \\
$\quad$ Total & 362.189 & 318 & & & \\
\hline
\end{tabular}

a. Dependent Variable: Study habits of distance learners

b. Predictors: (Constant), personal guidance and counselling
Statement (SHDL2) 'I spend hours reading before an examination to achieve my personal study goals after receiving personal guidance and counselling support services' had a mean of 3.28 and a standard deviation of 1.21 . This results indicate that out 319 participants, $33(10.3 \%)$ strongly agreed, $156(48.9 \%)$ agreed, 34(10.7\%) were undecided, 60(18.8\%) disagreed and 36(11.3\%) strongly disagreed that they spend hours reading before an examination to achieve their personal study goals after receiving guidance and counselling support services. This results show that the line statement mean score of 3.28 and standard deviation of 1.21 were above the composite mean score of 3.23 and standard deviation of 1.07. The implication of this result to this study indicate that spending hours reading before an examination by distance learners after receiving personal guidance and counselling support services positively affect their study habits. The study results support finding George [22] study finding that spending hours reading before examination enable distance learners to have mastery in their subject areas.

Statement (SHDL3) 'I do not worry so much about my study routine' had a mean of 3.03 and a standard deviation of 1.34 . This results indicate that out 319 participants, 4l(12.9\%) strongly agreed, $113(35.4 \%)$ agreed, $30(9.4 \%)$ were undecided, $83(26 \%)$ disagreed and 52(16.3\%) strongly disagreed that they do not worry so much about their study routine. The results shows that the line statement mean score of 3.03 and standard deviation of 1.34 were below the composite mean score of 3.23 and standard deviation of 1.07. The implication of the result suggest that distance learners do worry so much about their study routine, which negatively affect their study habits. The study results support Lancer and Eatough [6] who found that distance learners manifest negative study habits such as procrastination, spending too much time watching television,

Table 5: Coefficients for the regression of personal guidance and counselling and study habits of distance learners

\begin{tabular}{|c|c|c|c|c|c|}
\hline \multirow[t]{3}{*}{ Model } & \multicolumn{3}{|c|}{ Coefficients $^{\mathrm{a}}$} & \multirow[t]{3}{*}{$\mathrm{t}$} & \multirow[t]{3}{*}{ Sig. } \\
\hline & \multicolumn{2}{|c|}{ Unstandardized Coefficients } & \multirow{2}{*}{$\frac{\text { Standardized Coefficients }}{\text { Beta }}$} & & \\
\hline & $B$ & Std. Error & & & \\
\hline 1 (Constant) & 1.797 & 0.135 & & 13.356 & 0.000 \\
\hline Personal guidance and counselling & 0.461 & 0.040 & 0.543 & 11.576 & 0.000 \\
\hline
\end{tabular}

a. Dependent Variable: Study habits of distance learners

Table 6: Study habits of distance learners

\begin{tabular}{|c|c|c|c|c|c|c|c|}
\hline ITEMS & SA & A & U & $\mathrm{D}$ & SD & Mean & Std. dev \\
\hline SHDLI & $37(11.6 \%)$ & $161(50.5 \%)$ & $24(7.5 \%)$ & $61(19.1 \%)$ & $36(11.3 \%)$ & 3.32 & 1.23 \\
\hline SHDL2 & $33(10.3 \%)$ & $156(48.9 \%)$ & $34(10.7 \%)$ & $60(18.8 \%)$ & $36(11.3 \%)$ & 3.28 & 1.21 \\
\hline SHDL3 & $41(12.9 \%)$ & $113(35.4 \%)$ & $30(9.4 \%)$ & $83(26 \%)$ & $52(16.3 \%)$ & 3.03 & 1.34 \\
\hline SHDL4 & $38(12 \%)$ & $134(42 \%)$ & $39(12.2 \%)$ & $66(20.6 \%)$ & $42(13.2 \%)$ & 3.41 & 2.54 \\
\hline SHDL5 & $34(10.7 \%)$ & $141(44.2 \%)$ & $44(13.8 \%)$ & $57(17.8 \%)$ & $43(13.5 \%)$ & 3.21 & 1.24 \\
\hline SHDL6 & $32(10 \%)$ & $132(41.4 \%)$ & $22(6.9 \%)$ & $91(28.5 \%)$ & $42(13.2 \%)$ & 3.07 & 1.28 \\
\hline SHDL7 & $37(11.6 \%)$ & $151(47.4 \%)$ & $25(7.8 \%)$ & $60(18.8 \%)$ & $46(14.4 \%)$ & 3.23 & 1.29 \\
\hline SHDL8 & $43(13.5 \%)$ & $138(43.2 \%)$ & $32(10.0 \%)$ & $64(20.1 \%)$ & $42(13.2 \%)$ & 3.24 & 1.28 \\
\hline SHDL9 & $40(12.5 \%)$ & $141(44.2 \%)$ & $28(8.8 \%)$ & $68(21.3 \%)$ & $42(13.2 \%)$ & 3.22 & 1.28 \\
\hline SHDLI0 & $41(12.9 \%)$ & $145(45.4 \%)$ & $28(8.8 \%)$ & $68(21.3 \%)$ & $37(11.6 \%)$ & 3.27 & 1.26 \\
\hline SHDLII & $77(24.1 \%)$ & $128(40.2 \%)$ & $22(6.9 \%)$ & $59(18.5 \%)$ & $33(10.3 \%)$ & 3.34 & 1.31 \\
\hline $\begin{array}{l}\text { Composite mean and } \\
\text { Standard deviation }\end{array}$ & 44(13.8\%) & $139(43.6 \%)$ & $33(10.3 \%)$ & $63(19.8 \%)$ & $40(12.5 \%)$ & 3.23 & 1.07 \\
\hline
\end{tabular}


reading in bed and studying around loud noise indicator that they do not worry about their study routine.

Statement (SHDL4). 'I hand in my assignments in time after receiving personal guidance and counselling support services' had a mean of 3.41 and a standard deviation of 2.54. These results indicate that out of 319 participants, 38(12\%) strongly agreed, 134(42\%) agree, 39(12.2\%) were undecided, 66(20.6\%) disagreed and $42(13.2 \%)$ strongly disagreed that they hand in their assignments in time after receiving guidance and counselling support services. The results shows that the line statement mean score of 3.41 and standard deviation of 2.54 were above the composite mean score of 3.23 and standard deviation of 1.07. The result suggest that timely handing in of assignments by distance after receiving personal guidance and counselling support services positively affect their study habits. The study results support finding Hartung and Vess [2] that distance learners have work and family issues that takes away their study time and lack of personal guidance and counselling on how to cope with such issue result in handing $\mathrm{g}$ in assignment late.

Statement (SHDL5) 'I can balance my studying and looking for fees after personal guidance and counselling support services' had a mean of 3.41 and a standard deviation of 2.54. This results indicate that out 319 participants, 34(10.7\%) strongly agreed, $141(44.4 \%)$ agreed, $44(13.8 \%)$ were undecided, $57(17.8 \%)$ disagreed and $43(13.5 \%)$ strongly disagreed that they can balance their study and look for fees after receiving personal guidance and counselling support services. The results shows that the line statement mean score of 3.21 and standard deviation of 1.24 were slightly below the composite mean score of 3.23 and standard deviation of 1.07. The implication of this result to the study is that balancing of study and looking for fees by distance learners moderately affect their study habits. The study results support finding of Rambo and Odundo (2010) that distance learners are low-income earners and may spent time looking for money at the expense of their study.

Statement (SHDL6) 'My note writing techniques have improved after being personally guided and counselled' had a mean of 3.07 and a standard deviation of 1.28 . These results indicate that out of 319 participants, 32(10\%) strongly agreed, 132(41.4\%) agreed, $22(6.9 \%)$ were undecided. $91(28.5 \%)$ disagreed and $42(13.2 \%)$ strongly disagreed that their note writing techniques have improved after being guided and counselled. These results show that the line statement mean score of 3.07 and standard deviation of 1.28 were below the composite mean score of 3.23 and standard deviation of 1.07; this result implies that distance learners have not improved their note writing techniques after being guided and counselled and hence negatively affect their study habits. The study results support finding by Gatuba [23] who found out that personal guidance and counselling is the least learner support given to distance learners.

Statement (SHDL7). 'My reading habits have improved after being personally guided and counselled' had a mean of 3.23 and a standard deviation of 1.29 . The results indicate that out of 319 participants, 37(11.6\%) strongly agreed, 151(7.8\%) agreed,
$25(6.9 \%)$ were undecided, 60(18.8\%) disagreed and 46(14.4\%) strongly disagreed that their reading habits have improved after being guided and counselled. The results shows that the line statement mean score of 3.23 and standard deviation of 1.29 were similar to the composite mean score of 3.23 and standard deviation of 1.07 . The implication of this result to study that guidance and counselling support services improve reading habits of distance learners. The study results support finding of Reid [1] that suggest that personal guidance and counselling induced study habits facilitate progression rate of distance learners.

Statement (SHDL8) 'I now have sound study time due to personal guidance and counselling support services' had a mean of 3.24 and a standard deviation of 1.28 . These results indicate that out of 319 participants, 43(13.5\%) strongly agreed, 138(43.2\%) agreed, 32(10\%) were undecided, 64(20.1\%) disagreed and $42(13.2 \%)$ strongly disagreed that they have sound study time due to guidance and counselling support services. The results show that the line statement mean score of 3.24 and standard deviation of 1.28 were above the composite mean score of 3.23 and standard deviation of 1.07. The implication the result to this study is that this result implies that sound study habits is due to guidance and counselling support services. The study results support/contradicts report by University of Nairobi [24] indicate that effectively guidance and counselling promote development of sound study habits.

Statement (SHDL9) 'I joined a study group and studying through networking after receiving personal guidance and counselling support services' had a mean of 3.22 and a standard deviation of 1.28. This results indicate that out 319 participants, $40(12.5 \%)$ strongly agreed, $141(44.2 \%)$ agreed, 28(8.8\%) were undecided, 68(21.3\%) disagreed and $42(13.2 \%)$ strongly disagreed that they have joined a study group and study through networking after receiving guidance and counselling support services. This results show that the line statement mean score of 3.22 and standard deviation of 1.28 were similar to the composite mean score of 3.23 and standard deviation of 1.07. The implication of the result to the study that joining a study group and studying through networking by distance learners after receiving guidance and counselling support services positively affect their study habits. The study results supports finding of Bimrose, Kettunen and Goddard (2015) that networking promote development of study habits amongst distance learners.

Statement (SHDL10) 'I created a daily study routine after receiving guidance and counselling support services' had a mean of 3.27 and a standard deviation of 1.31. This results indicate that out of 319 participants, 41 (12.9\%) strongly agreed, $145(45.4 \%)$ agreed, 28(8.8\%) were undecided, 68(21.3\%) disagreed and $37(11.6 \%)$ strongly disagreed that they have created a daily study routine after receiving guidance and counselling support services. The results shows that the line statement mean score of 3.27 and standard deviation of 1.31 were above the composite mean score of 3.23 and standard deviation of 1.07 . The result implies that creation of study routine after receiving guidance and counselling support services by distance learners positively 
affect their study habits. The study results support Moor and Kersley [16] that found out that distance learners find it difficult to create daily study routine if not guided and counselled due to work and family roles that slow their completion of study assignments.

Statement (SHDL1l) 'I do have a better personal study time table after receiving guidance and counselling support services' had a mean of 3.34 and a standard deviation of 1.31 . This results indicate that out 319 participants, $77(24.1 \%)$ strongly agreed, $128(40.2 \%)$ agreed, $24(6.9 \%)$ were undecided, $59(18.5 \%)$ disagreed and 33(10.3\%) strongly disagreed that they have a better personal study timetable after receiving personally guidance and counselling support services. This results show that the line statement mean score of 3.34 and standard deviation of 1.31 were above the composite mean score of 3.23 and standard deviation of 1.07. The implication of the result to the study that personal guidance and counselling can help distance learners to make a better personal study time, which in turn positively affect their study habits. The study result contradict Fried and Irwin (2016) who found out that study habits of distance learners are not able to create a better personal study time.

\section{CONCLUSION AND RECOMMENDATION}

The study investigated the extent to which Personal guidance and counselling influence study habits of learners in Bachelor of education programme by distance learning of the University of Nairobi. The composite mean and composite deviation for the personal guidance and counselling from participants' perspective were 3.13 and 1.346 respectively. The implication of participants' responses based on the Likert scale indicate that personal guidance and counselling moderately influence study habits of distance learners. The overall correlation coefficient for personal guidance and counselling and study habits of distance learners from the perspective of participants (distance learners) was found to be 0.543 with a $\mathrm{p}$-value of $0.000<\alpha=0.05$. The Learners' counsellors are few and service providers lack skills in guidance and counselling. The study confirm that personal guidance and counselling are critical in distance education in enhancing study habits of distance learners. The study conclude that personal guidance and counselling support services moderately influence study habits of distance learners.

\section{Contributions to the Body of Knowledge}

The purpose of the study was to investigate the influence of personal guidance and counselling on study habits of learners in Bachelor of Education programme by distance learning of University of Nairobi. The study revealed that distance learners receive both face-to-face and online personal guidance and counselling which moderately influenced their study habits positively. The finding has contradicted Nyaga et al. [15] who found out that the influence of personal guidance and counselling on issues like study habits have remained a mirage in public universities in Kenya.
The study recommend that all universities providing distance education should provide effective personal guidance and counselling for psychological stability, in order to improve the study habits of distance learners. Online personal guidance and counselling should be improved to reach large numbers of distance learners within their localities. Universities should hire more counsellors in order to meet the personal guidance and counselling needs of distance learners. Distance learners should also be encouraged to put into practice various personal guidance and counselling strategies provided, in order to counter act any emerging issues that may negatively influence their study habits.

\section{ACKNOWLEDGEMENT}

I would like to express my profound gratitude to my supervisors, Dr. Anne Aseey of Department of Educational studies, Dr. Charles Kimamo of the Department of Psychology for their dedication, deep insights and guidance. My sincere appreciation goes to the University of Nairobi for giving me the opportunity to pursue my Doctoral Studies and engage in this research. Many thanks to the academic staff at the School of Open and Distance Learning (ODeL) for their support. Special thanks to my mentor Professor Rambo of University of Nairobi and Dr. Crispus Wawire of Kenyatta University for invaluable support. To my loving children, Lydia Obiero, Brian Obiero,Linnet Obiero,Lorraine Obiero and Billy Obiero., thank you for supporting and encouraging me. Not forgetting those who supported me in one way or another may God bless you all Finally, my special gratitude goes to the Almighty God for abundant grace and peace during this process. NB. The study had no funding.

\section{REFERENCES}

1. Reid ER. Length Matters! Exploratory Research into the Impact the Shortening of Guidance Appointments is having on Practice. Warwick: University of Warwick.@018.

2. Hartung $P$, Vess, L. Critical moments in career construction counselling. Journal of Vocational Behaviour. 2016: 97; 31-39.

3. Hooley, T. and Rice, S. Ensuring quality in career guidance: A critical review. British Journal of Guidance \&Counselling. 2019: 47(4); 472-486.

4. Egan G, Reese RJ. The Skilled Helper: A Problem-Management and Opportunity Development Approach to helping. 2019. (11 $1^{\text {th }}$ edition). Boston: Centage.

5. Tsikati AF. Factors contributing to effective guidance and counselling services at University of Eswatini. Global Journal of Guidance and Counselling in Schools: Current Perspectives. 2018: 8(3); 139-148.

6. Lancer N, Eatough V. One-to-one coaching as a catalyst for personal Development: An Interpretative Phenomenological Analysis of coaching undergraduates at a UK university. International Coaching Psychology Review. 2018: 13; 72-88.

7. Bakke, I.B., Haug, E.H. and Hooley, T. (2018). Moving from information provision to Co-careering. Integrated guidance as a new approach to e-guidance in Norway. Journal of the National Institute for Career Education and Counselling, forthcoming.

8. Julal F. Use of student support services among university students: Associations with Problem-focused coping, experience of personal difficulty and psychological distress. British Journal of Guidance \& Counselling. 2013: 41(4); 414-425.

9. Bozkurt A, Akgun-Ozbek E, Yilmazel S, Erdogdu E, Ucar H, Guler E. Trends in distance education research: A content analysis of journals 2009-2013. The International Review of Research in Open and Distributed Learning. 2015: 16(1); 331-363. 
10. Muchiri PW. Construction and evaluation of the effectiveness of a need based leaner support system: The case of the school of continuing and distance education Kenya, unpublished PhD thesis, University of Nairobi, Kenya. 2012.

11. Banda G, Kaphesi E. Students' perceptions of the open and distance learning Mode for initial primary teacher training in Malawi: A case of Lilongwe Teachers' College. Journal of Research in Open, Distance and ELearning. 2017: 1(1). Doi: 10.26841/2017e05

12. Wachira K. Utilization of Counselling Services among University Students in Kenya: A Case Study of Nairobi, Kenya. Unpublished M.A thesis, Department of Education Programme, University of Nairobi, Nairobi, Kenya. 2012

13. Tucker P. Evaluating distance education courses. Journal of Student Perception Assessment and Evaluation in Higher Education. 2003: 2(2): 165-177.

14. Kangai C, Rupande G, Rugonye S. Students' perceptions on the quality In addition, effectiveness of guidance and counselling services at the Zimbabwe Open University. In: The African Symposium. 2011: 11(1): 12-32

15. Nyaga $\mathrm{V}$, Oundo M, Kamoyo J. Effectiveness of guidance and counseling Services on development of student's academic competence. A comparative study of public and private universities in Kenya. International Journal of Education and Research. 2014: 2(4); 21-28.
16. Moore M G, Kearsley G. Distance education: A systems view of online learning. Belmont, CA: Wadsworth Cengage Learning. 2012.

17. Simpson A, Gibbs. Quality assurance in distance education: The challenges to be addressed. Higher Learners: A Retrospective Analysis. Journal of Youth and Adolescence. 2012: 11(2); 121 124.

18. Wango GM. A Synchronic Hermeneutic Phenomenological approach to Counselling Psychology in Contemporary Traditional Societies. 2013.

19. Krishna C. Students support services in distance higher Education in India. Critical Appraisals. IJRESS.2012: 2.

20. Bimrose J, Kettunen J, Goddard T. ICT-the new frontier? Pushing the Boundaries of careers practice. British Journal of Guidance $\varepsilon$ Counselling. 2015: 43(1); 8-23.

21. Hassan, T. Psychology of studying and passing mathematics examinations. Psychology for everyday living; Enugu; Agada publishers. 2013.

22. George D, Dixon S, Stansal E, Gelb SL, Pheri T. Time diary and Questionnaire assessment of factors associated with academic and personal success among university undergraduates. Journal of American College Health. 2016: 56(6); 706-715.

23. Gatuba, Influence of learner's support in enrolment of learners in Distance programme. PHD Thesis. University of Nairobi. 2012.

24. University of Nairobi annual report (2013). Nairobi. 